\title{
Tanggung Jawab Perdata Perawat/Mantri Atas Praktek Tindakan Sirkumsi
}

\author{
Irwan Dwi Rostanto ${ }^{1}$ \\ Universitas Trunojoyo Madura \\ Riesta Yogahastama ${ }^{2}$ \\ Universitas Trunojoyo Madura \\ riesta@trunojoyo.ac.id
}

\begin{abstract}
ABSTRAK
Polisi hendaknya dapat melakukan penegakan hukum dengan pendekatan yang lebih memenuhi keadilan, sehingga dalam penanganan perkara, tidak selalu harus menggunakan pendekatan represif. Cara yang dimaksudkan adalah dengan pendekatan keadilan restoratif, dan cara ini dapat dilakukan dalam perkara tertentu. Polisi dapat menggunakan pendekatan keadilan restoratif dalam penanganan perkara. karena polisi memeiliki kewenangan diskresi. Penggunaan kewenangan diskresi dalam penanganan perkara dengan pendekatan keadilan restoratif perlu diteliti, dengan tujuan untuk mengetahui dan menganalisis kebijakan kewenangan diskresi kepolisian dengan pendekatan keadilan restoratrif di Polres Mojokerto saat ini. Metode penelitian yang digunakan adalah yuridis sosiologis. Adapun pendekatan yang dilakukan adalah pendekatan kualitatif digabungkan dengan pendekatan perundang-undangan dan pendekatan kasus. Dapat disimpulkan bahwa kewenangan diskresi kepolisian dengan pendekatan keadilan restoratif terhadap penanganan kasus perkara perlu dikembangkan karena dalam KUHP, ada kemungkinan untuk mengedepankan pendekatan keadilan restoratif dalam penanganan perkara pidana. kewenangan diskresi kepolisian dengan pendekatan keadilan restoratif perlu disusun pedoman teknis pelaksanaan kewenangan diskresi kepolisian dengan pendekatan keadilan restoratif dalam penanganan.
\end{abstract}

Kata kunci : Keadilan Restoratif - Mediasi Penal

\begin{abstract}
The police should be enforcing the law with a more fulfill of justice, so that the handling the case, does not necessarily must use repressive approach. The way it is meant to restorative justice approach. because the police have discretionary authority. He use of discreationary authority in handling the cases with restorative justice approaches needs to be investigated, with the objective of identifying and to analiyze policy of the authority of the police discretion to restorative justice approaches in handling the case in Mojokerto at this time and perspective the authority of the police discretion with restorative justice. The research method used is sociological juridical. The approach taken is a qualitative approach combined with a statutory approach and a case approach. Concluded that the authority of the police discretion to restorative justice approach to handling cases need to be developed because of the draft Penal Code there is a possibility to put forward the restorative justice approach in handling criminal cases. The authority of the police discretion with restorative justice approach in handling cases the discretinary authority of the police to restorative justice approach should be made in the technical guidelines for the implementation of police discretionary powers with restorative justice for handling cases.
\end{abstract}

Keyword : restorative justice - penal mediation. 


\section{PENDAHULUAN}

Sirkumsi merupakan suatu tindakan memotong atau menghilangkan sebagian ataupun keseluruhan kulit bagian depan penis. Khitan bagi umat muslim bersifat wajib dan harus dilakukan oleh kaum laki-laki yang beragama muslim. Sirkumsi menurut sejarah telah dilakukan sejak tahun 3500 SM dengan ditemukannya peninggalan sejarah berupa prasasti yang terbuat dari tanah yang diperkirakan berasal dari peradaban Bangsa Babilonia dan Sumeria. Dengan ditemukannya prasasti tersebut menyebutkan bahwa pada zaman dahulu sirkumsi dilakukan dengan menggunakan metode pemberian balsam penghilang rasa sakit yang dioleskan dibagian depan bagian penis sebelum dilakukan sirkumsi, Pada zaman dahulu sirkumsi dilakukan dengan tujuan untuk kesehatan. Pelayanan yang diberikan oleh dokter kepada pasien merupakan bagian dari "pelayanan kesehatan".

Tenaga kesehatan adalah seorang petugas kesehatan yang profesional dalam segi perilaku dan tindakannya dalam memberikan pelayanan kepada masyarakat ataupun pasien yang didasarkan pada standar profesi yang berlaku, setiap tenaga kesehatan yang memberikan pelayanan kesehatan yang dilakukan di sarana atau fasilitas kesehatan memberikan pelayanan dengan mengacu pada kode etik profesi masingmasing yang telah dirumuskan oleh suatu organisasi ataupun perkumpulan profesi yang ada didalam bagian tenaga kesehatan. ${ }^{1}$

"Tenaga kesehatan" merupakan sesorang

1 Soekidjo Notoatmodjo, Etika \& Hukum Kesehatan, Rineka Cipta, Jakarta, 2010, hlm103. yang memiliki pengetahuan dan keterampilan pada bidang kesehatan dimana keterampilan dan keilmuan tersebut diperoleh berdasarkan pendidikan di bidang kesehatan, Apabila pendidikan telah diselesaikan maka setiap orang tersebut mengabdikan diri dibidang kesehatan untuk memberikan pelayanan kepada masyarakat dengan kewenangan yang dimiliki untuk melakukan upaya pelayanan kesehatan kepada masyarakat. $^{2}$ Tenaga kesehatan kemudian dibagi dalam beberapa kelompok yang sesuai dengan keilmuan dan keahliannya masing-masing yang pengelompokkan tersebut terbagi di antaranya adalah tenaga medis dan tenaga keperawatan. Pengelompokkan dalam tenaga kesehatan tersebut terbagi berdasarkan keilmuan dan pengetahuan setiap anggota tenaga kesehatan yang telah diatur didalam ketentuan "Undang Undang Nomor 36 Tahun 2014 tentang Tenaga Kesehatan". 3

Tenaga medis adalah suatu tenaga ahli yang terdapat dalam bidang kedokteran yang memiliki fungsi memberikan pelayanan medis kepada pasien yang pelayanannya tersebut menggunakan prosedur yang didasarkana atas bidang keilmuan serta berdasarkan "kode etik" dan dapat dipertanggung jawabkan dalam atas tindakan ataupun pelayanan yang telah diberikAN. ${ }^{4}$

Perawat merupakan seorang yang telah dinyatakan selesai dalam menempuh pendidikan dalam bidang keperawatan dan mengabdikan

2 Lihat Pasal 1 Angka 1 Undangundang Nomor 36 Tahun 2014 Tentang Tenaga Kesehatan

${ }^{3}$ Lihat Pasal 11 Undang-Undang Nomor 36 Tahun 2014 tentang Tenaga Kesehatan.

4Bustami, Penjamin Mutu Pelayanan Kesehatan dan Akseptabilitasnya, Erlangga, Jakarta 2011, hlm.32 
dirinya untuk memberikan pelayanan kesehatan kepada masyarakat berdasarkan kemampuan yang dimiliki serta tanggung jawab dan kewewenang dalam melaksanakan pelayanan/asuhan keperawatan di berbagai jenjang pelayanan keperawatan. ${ }^{5}$ Perawat dapat memberikan pelayanan kepada masyarakat apabila perawat tersebut telah memiliki izin untuk menjalankan pelayanan keperawatan, Izin yang perlu dimiliki perawat dalam menjalankan praktik pelayanan keperawatan adalah bukti kepimilikin Surat Tanda Registrasi Perawat dan Surat Izin Praktik Perawat.

Apabila ketentuan perizinan tersebut telah dipenuhi oleh perawat maka perawat dapat memberikan pelayanan keperawatan di fasilitas kesehatan umum maupun pelayanan keperawatan secara mandiri. Dengan adanya aturan yang mengatur mengenai praktik mandiri perawat diharapkan Tenaga Keperawatan dapat membantu peningkatan pelayanan kesehatan serta menjalankan tugas dan wewenangnya sesuai dengan peraturan yang telah ada. ${ }^{6}$ Sirkumsi pada umumnya dilakukan oleh dokter yang telah memiliki keahlian dalam tindakan pembedahan dan tidak menutup kemungkinan sirkumsi juga dapat dilakukan oleh perawat yang berada di daerah dan tidak ada tenaga medis di daerah tersebut. Peran Perawat dalam masyarakat sangatlah besar karena perawat bertugas untuk memberikan asuhan perawatan setelah pasien diberikan pelayanan oleh dokter. Tugas dan

5Kusnanto, Pengantar Profesi \& Praktik Keperawatan Profesional, EGC, Jakarta, 2004, hlm.75

6Lihat Pasal 4 Peraturan Menteri Kesehatan Republik Indonesia Nomor 26 Tahun 2019 wewenang perawat berdasarkan ketentuan yang berlaku menjelaskan bahwa perawat dalam memberikan pelayanan keperawatan hanya sebatas pemberi asuhan keperawatan, penyuluh konselor bagi klien dan perawat dapat menjalankan tugas berdasarkan pelimpahan wewenang serta pelaksana tugas dalam keadaan tertentu. $^{7}$

Berdasarkan ketentuan tersebut dapat disimpulkan bahwa perawat dalam menjalankan pelayanan keperawatan kepada klien ataupun pasien sesuai dengan tugas dan wewenang yang berlaku, Dalam pemberian pelayanan keperawatan dapat melakukan tindakan medis apabila perawat tersebut menerima pelimpahan wewenang dari tenaga medis terkait untuk menjalankan tugas yang dilimpahkan tersebut serta dalam keadaan dan keterbatsan tertentu perawat dapat memberikan pelayanan berupa tindakan medis apabila dalam daerah tersebut tempat perawat menjalankan tugas dalam keadaan keterbatasan tertentu tidak terdapat tenaga medis dan tidak ada fasiltas pelayanan kesehatan maka perawat dapat melakukan tindakan medis sesuai dengan kompetensi dan keilmuan yang dimilikinya. ${ }^{8}$

\section{METODE PENELITIAN}

Penelitian hukum merupakan suatu penelitian dengan dasar obyek terhadap peraturan, baik suatu ilmu atau aturan-aturan yang sifatnya dogmatis maupun yang berkaitan

${ }^{7}$ Lihat Pasal 16 Peraturan Menteri Kesehatan Republik Indonesia Nomor 26 Tahun 2019

${ }^{8}$ Lihat Pasal 20 Keputusan Menteri Kesehatan Republik Indonesia Nomor 1239 Tahun 2001.

Universitas Trunojoyo Madura 
dengan perilaku dan kehidupan yang terdapat didalam masyarakat. Pada dasarnya penelitian hukum tidak lain sebagai suatu kegiatan ilmiah yang didasarkan pada "metode, sistematika dan pemikiran tertentu". Dengan tujuan untuk mempelajari gejala hukum tertentu dengan jalan menganalisisnya.

Kecuali itu, maka juga diadakan pemeriksaan yang mendalam terhadap fakta hukum tersebut untuk kemudian mengusahakan suatu pemecahan atas permasalahanpermasalahan yang timbul di dalam gejala bersangkut. ${ }^{9}$ Penelitian ini menggunakan beberapa pendekatan. Pendekatan pertama adalah pendekatan perundang-undangan (statute approach) yang mempunyai makna "menelaah peraturan perundang-undangan dan mencari ratio legis lahirnya suatu undang-undang". ${ }^{10}$ Pendekatan perundang-undangan digunakan dalam penelitian ini, karena salah satu fokus penelitian menganalisis mengenai peraturan perundang-undangan.

\section{HASIL DAN PEMBAHASAN}

1. Syarat Tindakan Khitan Menurut Medis Yang Dilakukan Oleh Perawat

Sirkumsi menurut ilmu medis merupakan suatu tindakan memotong ataupun menghilangkan quluf (kulit yang menutupi kepala penis pada kelamin lakilaki). Sirkumsi dalam pandangan ilmu medis memiliki dampak yang sangat besar bagi tubuh dan dapat menghindarkan tubuh dari

\footnotetext{
${ }^{9}$ Peter Mahmud Marzuki, Penelitian Hukum Jakarta: Kencana,2005, hlm.25

10 Peter Mahmud Marzuki, Penelitian Hukum (Edisi Revisi), Prenadamedia Group, Jakarta, 2005, hlm.133-134.
}

berbagai macam penyakit dengan dipotongannya "Quluf” dapat mempermudah membersihkan bagian kepala penis setelah buang air kecil, apabila "Quluf" tidak dipotong maka akan tersisa air kencing tersebut didalamnya dan dapat beresiko timbulnya bakteri dan berakibat gejala penyakit kelamin. ${ }^{11}$

Sirkumsi pada umumnya dilakukan oleh Dokter karena Sirkumsi merupakan suatu tindakan medis dan hanya dijalankan oleh tenaga kesehatan yang sesuai dengan bidang serta kemampuannya. Sirkumsi tergolong sebagai tindakan medis karena adanya bagian tubuh yang harus dihilangkan dan cara menghilangkang atau memotong membutuhkan tindakan medis. Tindakan medis merupakan suatu tindakan kedokteran yang mengandung risiko tinggi dalam pelaksanaannya, tindakan medis dilakukan berdasarkan probabilitas tertentu dan dalam prosesnya mengandung risiko kematian ataupun kecacatan. Untuk pengertian tindakan medis telah dijelaskan dalam "Pasal 1 angka 5 Peraturan Menteri Kesehatan Nomor 290 Tahun 2008” yaitu: ${ }^{12}$

"Tindakan Kedokteran yang mengandung risiko tinggi adalah tindakan medis yang berdasarkan tingkat probabilitas tertentu, dapat mengakibatkan kematian atau kecacatan.",

Berdasarkan penjelasan yang terdapat dalam "Pasal 1 Angka 5 Permenkes Nomor

11 Ibrahim Majdi as Sayid, Op, cit, hlm.

12 Lihat Pasal 1 Angka 5 Peraturan Menteri Kesehatan Nomor 290 Tahun 2008 Tentang Persetujuan Tindakan Kodekteran 
290 Tahun 2008" telah jelas bahwa tindakan medis merupakan suatu tindakan kodekteran yang tindakannya tersebut mengandung risiko yang besar maka dari itu dalam proses sirkumsi dilakukan oleh tenaga kesehatan yang sesuai dengan bidang serta keilmuannya karena sirkumsi merupakan suatu tindakan medis dengan risiko yang tinggi karena sirkumsi merupakan suatu proses menghilangkan ataupun memotong bagian kulit pada alat kelamin laki-laki.

Perawat merupakan suatu profesi yang memiliki fungsi autonomi yang didefinisikan sebagai fungsi profesional dalam keperawatan. Fungsi profesional dalam keperawatan yaitu memiliki fungsi untuk membantu pasien dalam menemukan kebutuhan pasien yang bersifat segera. Karena tugas tersebut merupakan tanggung jawab perawat untuk mengetahui kebutuhan serta membantu untuk memenuhinya. ${ }^{13}$

Pelayanan keperawatan didasarkan dari ilmu dan kiat keperawatan dalam menberikan pelayanan keperawatan dapat dilakukan di fasilitas pelayanan kesehatan, Dalam pemberian pelayanan kesehatan perawat haruslah memenuhi syarat yang dibutuhkan untuk menjalankan proses pelayanan praktik keperawatan di fasilitas umum yang antara lain berupa kepimilikan Surat Tanda Registrasi Perawat yang merupakan bentuk tertulis yang diberikan konsil perawat kepada Perawat sebagai bukti bahwa perawat telah terregistrasi sedangkan untuk menjalankan

13 Suwignyo. Pengaruh Manajemen Asuhan Keperawatan dan Motivasi Berprestasi, Gramedia Pustaka Utama, Jakarta 2007, hlm.33 pelayanan praktik keperawatan perlu memiliki Surat Izin Praktik Perawat yang merupakan bukti tertulis yang diberikan oleh Pemerintah Kabupaten/Kota kepada perawat sebagai pemberian kewenangan kepada perawat untuk dapat menjalankan praktik keperawatan. Ketentuan tersebut merupakan ketentuan yang harus dipenuhi oleh perawat dalam proses pemberian pelayanan praktik keperawatan di fasilitas umum yang di atur di dalam "Peraturan Menteri Kesehatan Nomor 26 tahun 2019". 14

Perawat dalam menjalankan pelayanan praktik keperawatan memiliki wewenang dalam menyelenggarakan asuhan keperawatan dalam bidang upaya peningkatan kesehatan serta memberikan penyuluhan dan konseling untuk klien. Dalam pelayanan praktik keperawatan, perawat juga melaksanakan tugas berdasarkan pelimpahan wewenang meski perawat tersebut menjalankan pelayanan praktik keperawatan di fasilitas umum, dengan adanya pelimpahan wewenang yang diterima perawat dalam praktik keperawatan tidak menutup kemungkinan perawat untuk menjalankan tindakan medis kepada klien seperti tindak medis sirkumsi. ${ }^{15}$

Untuk menjalankan tindakan medis seperti sirkumsi perawat dapat melakukan tindakan medis tersebut berdasarkan pelimpahan wewenang dari Dokter, Pelimpahan wewenang dapat berupa

${ }^{14}$ Lihat Pasal 1 Angka 9 Peraturan Menteri Kesehatan Nomor 26 Tahun 2019

15 Lihat Pasal 37 Peraturan Menteri Kesehatan Nomor 26 Tahun 2019

Universitas Trunojoyo Madura 
pelimpahan wewenang secara mandat dan pelimpahan wewenang secara delegatif. Perawat dalam menjalankan pelimpahan wewenang secara mandat, perawat dapat menjalankan suatu tindakan medis dibawah pengawasan tenaga medis yang telah memberi pelimpahan wewenang terhadap perawat, Sedangkan pelimpahan wewenang secara delegatif perawat dapat melakukan sesuatu tindakan medis dari Dokter yang disertai dengan pelimpahan tanggung jawab untuk perawat yang melakukan tindakan medis. ${ }^{16}$

Berdasarkan pengertian tersebut dapat disimpulkan bahwa perawat dalam menjalankan tindakan medis seperti tindakan medis sirkumsi haruslah didasarkan adanya pelimpahan wewenang dari Dokter agar dapat menjalankan suatu tindakan medis karena tugas dan wewenang perawat sendiri berupa pemberi asuhan keperawatan dalam bidang peningkatan upaya kesehatan dan memberikan penyuluhan serta konseling kepada klien. Apabila perawat dalam praktek keperawatan menjalankan tindakan medis seperti tindakan medis berupa sirkumsi tanpa adanya pelimpahan wewenang yang diterima maka perawat tersebut telah melanggar ketentuan yang berlaku tentang tugas dan wewenang perawat.

Hal ini sebagai peristiwa yang terjadi di banyumas terdapat seorang perawat melakukan tindakan medis berupa sirkumsi dan atas tindakannya tersebut pasien ataupun

16 Lihat Pasal 28 Peraturan Menteri Kesehatan Nomor 26 Tahun 2019 kliennya mengalami kecacatan yang harus dideritanya karena bagian depan kelaminnya terpotong saat dilakukan sirkumsi oleh perawat tersebut. Perawat yang telah melakukan tindakan medis berupa sirkumsi yang menyebabkan terpotongnya bagian depan kelamin pasien atau kliennya tersebut bertanggung jawab atas tindakannya tersebut dengan melakukan perjanjian tertulis bahwa perawat tersebut akan bertanggung jawab sepenuhnya sampai korban tersebut dinyatakan sembuh menerut medis.

Akan tetapi pertanggung jawaban perawat tidaklah menyelesaikan permasalahan yang telah dibuatnya terkait tindakan medis sirkumsi yang dilakukan perawat karena korban dinyatakan mengalami kecacatan pada alat kelaminnya dan korban yang didampingi ibunya dan Komisi Perlindungan Anak berencana untuk melaporkan tindakan perawat tersebut yang telah menyebabkan kerugian kepada korban yaitu kecacatan yang harus dialami korban pada alat kelaminnya kepada pihak yang berwenang.Berdasarkan contoh kasus tersebut dapat disimpulkan bahwa masih terdapat pelanggaran yang dilakukan oleh perawat mengenai wewenang melakukan tindakan medis terutama perawat yang ada didaerah.

Apabila kasus tersebut dikaitkan dengan ketentuan Undang-undang Nomor 36 Tahun 2014 Pasal 84 tentang Tenaga Kesehatan maka perawat yang telah melakukan sirkumsi kepada pasien atau kliennya yang mengakibatkan kerugian berupa kecacatan yang harus dialami oleh pasien atau klien 
tersebut maka perawat tersebut dapat dikenai sanksi pidana penjara paling lama 3 tahun karena dalam Pasal 84 mengatur bahwa setiap tenaga kesehatan yang melakukan kelalain berat dan menyebabkan luka berat yang dialami oleh penerima pelayanan kesehatan maka tenaga kesehatan yang telah memberikan pelayanan tersebut dapat dikenai sanksi pidana penjara akibat kelalainnya tersebut yang mengakibatkan luka berat ataupun kecacatan yang diterima oleh penerima pelayanan kesehatan ataupun pasien dan klien.

Karena tindakan medis merupakan tindakan yang dapat dilakukan oleh dokter dan tindakan medis memiliki resiko yang besar dalam pelaksanaannya, Perawat dapat melakukan tindakan medis apabila perawat tersebut telah memperoleh pelimpahan wewenang dari tenaga medis yaitu dokter yang memberikan pelimpahan wewenang dalam melakukan tindakan medis yang dapat dilakukan perawat berupa pelimpahan wewenang secara delegatif dan pelimpahan wewenang secara mandat. ${ }^{17}$

\section{Hubungan Hukum Perawat Dengan} Pasien Di Dalam Praktek Keperawatan Yang Ada Dalam Klinik Pada Tindakan Sirkumsi.

Praktek keperawatan yang ada dalam klinik terdapat suatu hubungan hukum yang timbul antara perawat dan pasien, Adanya hubungan hukum dalam praktik keperawatan

17 Lihat Pasal 84 Undang-Undang Nomor 36 Tahun 2014 tentang Tenaga Kesehatan. yang ada dalam klinik bertujuan agar pasien mengetahui bahwa setiap tindakan tenaga medis mengandung resiko yang sangat tinggi maka diperlukan suatu persetujuan atau perjanjian sebelum adanya tindakan tenaga medis dari tenaga kesehatan terkait. Persetujuan atau perjanjian yang diberikan oleh tenaga kesehatan kepada pasien dapat berupa perjanjian atau persetujuan tertulis maupun lisan, Adanya persetujuan atau perjanjian dalam praktik keperawatan yang ada dalam klinik merupakan syarat yang harus dipenuhi bagi setiap tenaga kesehatan yang menjalankan pelayanan kesehatan karena syarat tersebut telah diatur didalam peraturan yang ada dan harus diterapkan bagi setiap tenaga kesehatan yang menjalankan pelayanan kesehatan. ${ }^{18}$

Hubungan hukum yang timbul dalam praktek keperawatan yang terdapat dalam klinik antara perawat dan pasien adalah hubungan hukum yang berupa perjanjian terapeutik, Perjanjian terapeutik merupakan suatu perjanjian yang dikenal dalam bidang pelayanan kesehatan. Perjanjian terapeutik disebut dengan kontrak terapeutik yang merupakan suatu kontrak atau perjanjian yang dibuat antara pasien dengan tenaga kesehatan dan dokter ataupun dokter gigi yang memiliki tujuan dalam perjanjian atau kontrak tersebut berupa upaya penyembuhan dan pelayanan medis yang ditujukan kepada pasien sesuai dengan kesepakatan yang telah dibuat sebelumnya dan pasien berkewajiban membayar biaya penyembuhan ataupun

18 Lihat Pasal 68 Undang-undang Nomor 36 Tahun 2014.

Universitas Trunojoyo Madura 
pelayanan medis yang telah diberikan oleh tenaga kesehatan dan dokter ataupun dokter gigi. ${ }^{19}$

Perjanjian terapeutik berdasarkan ketentuan "KUHPerdata" dirasa kurang mumpuni karena perjanjian tersebut hanya ada dalam pelayanan kesehatan, Akan tetapi perjanjian terapeutik tergolong perjanjian yang sah menurut Undang-undang karena unsur perjanjian yang ada dalam perjanjian terapeutik telah sesuai dengan 'Pasal 1319 KUHPerdata" yang berisi bahwa suatu perjanjian yang memiliki nama khusus, maupun perjanjian yang tidak dikenal dengan suatu nama tertentu tunduk pada peraturan umum yang telah mengaturnya. ${ }^{20}$ Berdasarkan pengertian tersebut dapat disimpulkan bahwa hubungan hukum yang ada dalam praktek keperawatan yang ada dalam klinik antara perawat dan pasien berupa perjanjian ataupun kontrak terapeutik, Perjanjian terapeutik antara perawat dan pasien berisi tentang upaya penyembuhan dan pelayanan medis yang diberikan perawat kepada pasien berdasarkan kesepakatan yang telah dibuat sebelumnya. Dalam perjanjian terapeutik perawat dapat memberikan tindakan medis berupa sirkumsi kepada pasien apabila perawat tersebut telah memperoleh pelimpahan wewenang dari Dokter untuk menjalankan suatu tindakan medis.

- Pelimpihan wewenang adalah suatu pelaksanan tugas yang dijalankan oleh

19 Salim H.S. Hukum Kontrak:Teori \& Teknik Penyusunan Kontrak. Sinar Grafika, Jakarta, 2004, hlm.45

20Lihat Pasal 1319 Kitab UndangUndang Hukum Perdata. perawat berdasarkan wewenang yang telah diberikan oleh tenaga medis secara tertulis kepada perawat untuk melaksanakan suatu tindakan medis dan melakukan evaluasi terkait pelaksanaan tindakan medis yang telah dijalankan. ${ }^{21}$

Perawat menjalankan tugas berdasarkan pelimpahan wewenang dilaksanakan berdasarkan adanya pelimpahan wewenang dari tenaga medis untuk melakukan suatu tindakan medis dan memberikan evaluasi dalam pelaksanaan tindak medis yang telah dilakukan perawat tersebut dan berdasarkan pada pelaksanaan program pemerintah ${ }^{22}$. Pelimpahan wewenang perawat untuk menjalankan suatu tindakan medis terdapat dua macam pelimpahan wewenang yaitu pelimpahan wewenang secara delagatif dan secara mandat.

Pelimpahan wewenang delegatif adalah suatu wewenang yang diberikan tenaga medis kepada perawat secara tertulis untuk melakukan suatu tindakan medis dengan disertai pelimpahan tanggung jawab yang dibebankan kepada perawat. Dalam pelimpahan wewenang secara delegatif perawat dapat melakukan suatu tindakan medis kepada pasien karena perawat tersebut telah memperoleh wewenang secara tertulis dari tenaga medis terkait, Dalam menjalankan tindakan medis seperti tindakan medis sirkumsi apabila terdapat suatu kerugian yang dialami oleh pasien maka perawatlah yang

21 Lihat Pasal 32 Undang-Undang Nomor 38 Tahun 2014 Tentang Keperawatan.

22 Lihat Pasal 27 Peraturan Menteri Kesehatan Nomor 26 Tahun 2019.

Universitas Trunojoyo Madura 
harus bertanggung jawab atas tindakannya tersebut dikarenakan pelimpahan wewenang secara delegatif bukan hanya wewenang untuk melakukan tindakan medis saja yang dapat dilakukan oleh perawat akan tetapi pelimpahan tanggung jawab dari tenaga medis harus ditanggung oleh perawat dalam menjalankan pelimpahan wewenang secara delegatif. $^{23}$

Berdasarkan pengertian yang telah tertera diatas maka dapat disimpulkan bahwa perawat dapat menjalankan suatu tindakan medis dengan di dasari adanya suatu pelimpahan wewenang yang diberikan tenaga medis kepada perawat. Pelimpahan wewenang secara delegatif yang diterima oleh perawat memperbolehkan perawat untuk melakukan suatu tindakan medis kepada klien atau pasien, Akan tetapi dalam menjalankan tindakan medis yang dilakukan perawat kepada pasien atau klien terdapat suatu kerugian yang dialami oleh pasien atau klien maka pasien atau klien tersebut dapat meminta pertanggung jawaban sepenuhnya kepada perawat dikarenakan dalam pelimpahan wewenang secara delegatif tersebut bukan hanya wewenang melakukan tindakan medis saja yang dapat dilakukan oleh perawat akan tetapi tanggung jawab dari tenaga medis yang telah melimpahkan wewenang dan tanggung jawabnya dalam pelimpahan wewenang secara delegatif juga harus diterima oleh perawat selaku penerima pelimpahan wewenang secara delegatif.

Pelimpahan wewenang mandat adalah

23 Lihat Pasal 28 Angka 4 Peraturan Menteri Kesehatan Nomor 26 Tahun 2019. suatu wewenang yang diberikan tenaga medis kepada perawat untuk menjalankan suatu tindakan medis dengan pengawasan dari tenaga medis terkait yang melimpahkan wewenangnya tersebut. Dalam pelimpahan wewenang secara mandat perawat dapat melukan suatu tindakan medis apabila ada pernyataan lisan maupun pernyataan tertulis dari tenaga medis terkait yang bertanggung jawab atas pelimpahan wewenang tersebut kepada perawat. ${ }^{24}$

Berdasarkan pengertian tersebut maka dapat disimpulkan bahwa perawat dalam menjalankan tindakan medis karena adanya suatu pelimpahan wewenang yang diberikan oleh dokter kepada perawat. Dalam menjalankan pelimpahan wewenang secara mandat perawat menjalankan tindakan medis dengan adanya pengawasan dari tenaga medis terkait untuk menjalankan suatu tindakan medis dan apabila dalam proses tindakan medis yang dijalankan perawat atas dasar pelimpahan wewenang secara mandat terdapat suatu kerugian yang dialami oleh klien atau pasien maka dalam pelimpahan wewenang secara mandat yang dijalankan oleh perawat yang bertanggung jawab adalah tenaga medis terkait yang telah memberikan pelimpahan wewenang secara mandat kepada perawat.

Perawat dapat menjalankan tindakan medis tanpa adanya pelimpahan wewenang dari tenaga medis terkait apabila dalam keadaan darurat sebagai pertolongan pertama yang bertujuan untuk menyelamatkan nyawa

24 Lihat Pasal 28 Angka 3 Peraturan Menteri Kesehatan Nomor 26 Tahun 2019.

Universitas Trunojoyo Madura 
klien dan mencegah kecacatan lebih lanjut yang dapat diderita oleh klien atau pasien. Tindakan medis yang dilakukan perawat dalam keadaan darurat dijalankan berdasarkan hasil evaluasi perawat yang sesuai dengan keilmuan yang dimiliki oleh perawat, Apabila perawat telah memberikan tindakan medis kepada klien atau pasien dalam keadaan darurat maka perawat wajib untuk merujuk klien atau pasien kepada dokter ataupun Fasilitas Pelayanan Kesehatan setelah pertolongan pertama yang diberikan perawat telah selesai dilakukan. ${ }^{25}$

Keadaan Gawat Darurat merupakan dua kata yang memiliki arti masing-masing, Gawat adalah suatu keadaan yang dapat mengancam nyawa suatu individu sedangkan darurat memiliki pengertian perlunya mendapatkan suatu penanganan ataupun pertolongan dan tindakan segera untuk menghilangkan ancaman nyawa korban. Jadi keadaan gawat darurat dapat disimpulkan suatu keadaan yang dapat mengancam nyawa suatu korban yang perlu untuk diberikan suatu tindakan segera untuk menghindari kecacatan bahkan kematian yang dapat dialami oleh korban. ${ }^{26}$

Keadaan kegawatdaruratan perawat maupun tenaga kesehatan terkait diwajibkan untuk memberikan pertolongan kepada korban yang sedang dalam keadaan kegawatdaruratan agar korban terselamatkan dari potensi kehilangan nyawa maupun

25 Lihat Pasal 33 Peraturan Menteri Kesehatan Nomor 26 Tahun 2019.

26 Hutabarat, R. Y., \& Putra, C. S. Asuhan Keperawatan Kegawatdaruratan. In Media, Bogor, 2016, hlm.22 kecacatan yang dapat diderita oleh korban, Apabila dalam keadaan kegawat daruratan perawat ataupun tenaga kesehatan terkait tidak memberikan pertolongan pertama kepada korban yang sedang dalam keadaan kegawatdaruratan maka perawat ataupun tenaga kesehatan terkait dapat dikenakan sanksi sebagaimana yang telah diatur didalam "Pasal 190 Ayat 1 Undang-Undang Nomor 36 Tahun 2009 tentang Kesehatan” yang mengatur sebagai berikut, ${ }^{27}$ "Pimpinan fasilitas pelayanan kesehatan dan/atau tenaga kesehatan yang melakukan praktik atau pekerjaan pada fasilitas pelayanan kesehatan yang dengan sengaja tidak memberikan pertolongan pertama terhadap pasien yang dalam keadaan gawat darurat sebagaimana dimaksud dalam Pasal 32 ayat (2) atau Pasal 85 ayat (2) dipidana dengan pidana penjara paling lama 2 (dua) tahun dan denda paling banyak Rp 200.000.000,00 (dua ratus juta rupiah)".

Berdasarkan pengertian tersebut dapat disimpulkan bahwa perawat dapat menjalankan suatu tindakan medis tanpa adanya suatu pelimpahan wewenang dari tenaga medis terkait yang harus dimiliki terlebih dahulu oleh perawat. Perawat dapat menjalankan suatu tindakan medis apabila dalam keadaan kegawatdaruratan yang dapat mengancam nyawa dan mencegah kecacatan yang dapat diderita oleh klien atau pasien dikarenakan dalam keadan kegawatdarutan perawat maupun tenaga kesehatan terkait berkewajiban untuk memberikan pertolongan

27 Lihat Pasal 190 Ayat 1 UndangUndang Nomor 36 Tahun 2009.

Universitas Trunojoyo Madura 
kepada klien atau pasien, Setelah perawat memberikan pertolongan kepada klien atau pasien dalam keadaan kegawat daruratan maka perawat diwajibkan untuk merujuk pasien atau klien kepada dokter ataupun merujuk langsung pada Fasilitas Pelayanan Kesehatan terdekat untuk mendapatkan pertolongan dari tenaga medis terkait.

Perawat dalam pelaksanaan tugas pada keadaan keterbatasan tertentu adalah suatu tugas yang harus dijalankan oleh perawat yang tugas tersebut merupakan suatu penugasan pemerintah yang dilaksanakan oleh perawat pada keadaan tidak adanya tenaga medis ataupun tenaga kefarmasian di suatu wilayah tempat perawat menjalankan penugasan. Dalam menjalankan pelaksanaan tugas dalam keadaan keterbatasan tertentu dilaksanakan dengan memperhatikan kompetensi perawat dan dalam menjalankan tugas dalam keadaan keterbatasan perawat juga dibekali dengan pelatihan dan orientasi yang dilakukan oleh Kepala dinas kesehatan Pemerintah Kabupaten/Kota.

Perawat dalam menjalankan tugas pada keadaan keterbatasan tertentu memiliki kewenangan untuk melakukan pengobatan untuk penyakit umum apabila tidak ada tenaga medis terkait didaerah tempat perawat menjalankan tugas dalam keadaan keterbatasan dan perawat juga berwenang melakukan pelayanan kefarmasian secara terbatas apabila tidak ada tenaga kefarmasian. $^{28}$

Berdasarkan pengertian tersebut

28 Lihat Pasal 30 Peraturan Menteri Kesehatan Nomor 26 Tahun 2019. perawat dalam menjalankan tugas pada keadaan keterbatasan tertentu telah dibekali pelatihan dan orientasi oleh Kepala dinas kesehatan Pemerintah Kabupaten/Kota sebelum menjalankan tugas pada keadaan keterbatasan tertentu. Perawat dalam menjalankan tugas dalam keadaan keterbatasan tertentu memiliki wewenang untuk memberikan pelayanan tindakan medis berupa pengobatan untuk penyakit umum dan perawat juga diberi wewenang untuk memberikan pelayanan kefarmasian apabila dalam daerah tersebut tidak terdapat tenaga medis ataupun tenaga kefarmasian.

Apabila dalam pelaksanaan tugas pada keadaan keterbatasan tertentu perawat diduga melakukan tindakan medis diluar kewenangannya seperti melakukan tindakan medis berupa sirkumsi dan tindakan medis yang dilakukan perawat berakibat kerugian berupa kecacatan yang harus diderita oleh pasien/klien maka perawat tersebut telah melanggar ketentuan yang telah diatur dalam ketentuan tentang tugas dan wewenang perawat dalam menjalankan tugas dalam keadaan keterbatasan tertentu yang diatur dalam "Pasal 30 Peraturan Menteri Kesehatan Nomor 26 Tahun 2019 tentang Peraturan Pelaksanaan Undang Undang Nomor 38 Tahun 2014 Tentang Keperawatan”.

\section{Akibat Hukum Terkait Tindakan} Sirkumsi Yang Di Jalankan Perawat Dalam Praktek Keperawatan Yang Ada Dalam Klinik

Akibat hukum yang terjadi dalam praktek keperawatan yang ada pada klinik 
dapat terjadi karena adanya faktor kelalaian dan adanya perbuatan melanggar hukum yang dilakukan oleh perawat tersebut. Dalam menjalankan praktik keperawatan, perawat dapat menjalankan suatu tindakan medis seperti tindakan medis sirkumsi apabila perawat telah menerima surat delegasi tertulis maupun lisan dari tenaga medis terkait yaitu Dokter. Apabila perawat dengan sengaja melakukan tindakan medis kepada pasien dalam praktek keperawatan tanpa adanya izin ataupun delegasi dari tenaga medis dan menyebabkan kerugian kepada pasien maka perawat tersebut dapat dinyatakan telah melanggar hukum karena perbuatannya tersebut.

Praktek keperawatan yag ada dalam klinik, perawat yang dengan sengaja melakukan perbuatan melanggar hukum apabila pasien tersebut mengalami kerugian pada dirinya. Perbuatan melanggar hukum memiliki pengertian apabila setiap perbuatan yang melanggar hukum dan memberikan suatu kerugian kepada orang lain mewajibkan bagi orang yang telah menimbulkan kerugian tersebut karena kesalahan yang telah dibuatnya untuk menggantikan kerugian yang telah dialami oleh orang tersebut. ${ }^{29}$

Berdasarkan pengertian tersebut maka perawat berkewajiban untuk memberikan ganti rugi kepada pasien yang telah mengalami kerugian karena perbuatan dan keselahan yang telah dibuatnya dan pasien yang telah dirugikan karena perbuatan ataupun kesalahan yang telah dibuat oleh

29 Lihat Pasal 1365 Kitab Undangundang Hukum Perdata. perawat berwenang untuk menuntut kerugian kepada perawat atas tindakan yang telah dilakukan perawat kepada pasien. Pertanggung jawaban hukum yang telah diperbuat oleh perawat dalam praktek pelayanan kesehatan dapat dilihat dari tiga pembidangan hukum yang ada, yaitu pertanggung jawaban menurut hukum keperdataan, hukum pidana dan hukum administrasi. $^{30}$

Pelimpahan wewenang terdiri dari dua macam, Pelimpahan wewenang secara mandat dan pelimpahan wewenang secara delegatif. Pelimpahan wewenang mandat adalah suatu pelimpahan wewenang yang dilakukan oleh pejabat pemerintah yang memiliki posisi lebih tinggi yang memberikan pelimpahan kewenangan kepada pejabat pemerintahan yang lebih rendah dibawahnya dengan tanggung jawab serta tanggung gugat dalam pelimpahan wewenang secara mandat tersebut masih berada pada pemberi wewenang, sedangkan pelimpahan wewenang secara delegatif memiliki kesamaan dalam pemberian wewenangnya dengan pelimpahan mandat yaitu dilakukan oleh pejabat pemerintahan yang memberikan wewenangnya kepada pejabat pemerintahan dibawahnya, akan tetapi dalam pelimpahan secara delegasi tanggung jawab dan tanggung gugatnya beralih sepenuhnya kepada penerima pelimpahan wewenang secara

30 Cecep Tribowo, Hukum Keperawatan, Yogyakarta, Cet I, Pustaka Book Publisher, 2010, hlm.43-44

Universitas Trunojoyo Madura 
delegatif. $^{31}$

Pelimpahan wewenang secara mandat adalah suatu wewenang yang diberikan oleh dokter kepada perawat untuk menjalankan suatu tindakan medis. Dalam menjalankan tindakan medis berdasarkan pelimpahan wewenang secara mandat perawat menjalankan tindakan medis dengan pengawasan dokter yang telah memberikan wewenang kepada perawat untuk melakukan tindakan medis. Dalam menjalankan tindakan medis atas dasar adanya pelimpahan wewenang secara mandat perawat dapat melakukan tindakan medis berupa memberikan terapi parental, menjahit luka serta melakukan tindakan medis lainnya yang sesuai dengan kemampuan dan kompetensi perawat tersebut.

Apabila dalam melakukan tindakan medis berdasarkan pelimpahan wewenang mandat terjadi suatu kerugian yang dialami oleh pasien atau klien atas dasar tindakan medis yang dilakukan oleh perawat maka pertanggung jawaban hukum tidak sepenuhnya ditanggung oleh perawat akan tetapi pemberi pelimpahan wewenang secara mandat yaitu dokter yang menanggungnya selaku pemberi pelimpahan wewenang karena tindakan medis yang dilakukan oleh perawat dijalankan dengan pengawasan tenaga medis selaku pemberi wewenang untuk menjalankan tindakan medis oleh perawat. $^{32}$

31 Lihat pasal 1 Peraturan Menteri Kesehatan Nomor 9 Tahun 2019.

32 Lihat Pasal 32 Undang-Undang Nomor 38 Tahun 2014 tentang Keperawatan.
Pelimpahan wewenang delegatif merupakan suatu wewenang yang diperoleh perawat untuk menjalankan tindakan medis berdasarkan pelimpahan wewenang yang diberikan oleh dokter secara tertulis atau dapat disebut sebagai pelimpahan wewenang secara delegatif. Dalam menjalankan tindakan medis atas dasar pelimpahan wewenang secara delegatif perawat dapat melakukan tindakan medis kepada klien ataupun pasiennya dan tanggung jawab serta tanggung gugat yang diberikan dokter selaku pemberi wewenang berdasarkan pelimpahan wewenang secara delegatif harus diterima oleh perawat selaku penerima pelimpahan wewenang secara delegatif. Pelimpahan wewenang secara delegatif diberikan oleh dokter kepada perawat profesi dan perawat vokasi yang telah terlatih. Perawat profesi adalah seorang perawat yang bersedia bertanggung jawab dan memiliki wewenang untuk memberikan pelayanan keperawatan secara mandiri dan melakukan kolaborasi dengan tenaga kesehatan lain dalam memberikan pelayanan yang sesuai dengan kewenangannya $^{33}$.

Sedangkan perawat vokasi merupakan perawat dengan program pendidikan rendah yaitu Diploma Tiga Keperawatan. ${ }^{34}$ Apabila perawat dalam menjalankan tindakan medis berdasarkan pelimpahan wewenang secara delegatif terjadi suatu kerugian yang dialami

33 Depkes RI. 2002. Standar Tenaga Keperawatan di Rumah Sakit, Direktorat Pelayanan Keperawatan Direktoral Jenderal Pelayanan Medik.

34 Lihat Pasal 6 Undang-Undang Nomor 38 Tahun 2014 tentang Keperawatan.

Universitas Trunojoyo Madura 
oleh pasien atau kliennya maka pasien atau klien tersebut berhak untuk menuntut ganti rugi sepenuhnya kepada perawat karena dalam pelimpahan wewenang secara delegatif bukan hanya wewenang untuk melakukan tindakan medis saja yang diberikan dokter kepada perawat akan tetapi tanggung jawab dan tanggung gugat juga sepenuhnya beralih kepada penerima pelimpahan wewenang secara delegatif yaitu perawat.

Berdasarkan pengertian tersebut dapat disimpulkan bahwa dalam menjalankan tindakan medis berdasarkan pelimpahan wewenang dari dokter, Perawat dapat memberikan tindakan medis kepada pasien ataupun kliennya dengan memperhatikan kemampuan serta kompetensi perawat dalam memberikan tindakan medis kepada pasien maupun kliennya agar tidak terjadi suatu kerugian yang dapat dialami pasien ataupun klien selaku penerima pelayanan tindakan medis yang diberikan perawat. Karena dalam menjalankan tugas berdasarkan pelimpahan wewenang memiliki perbedaan dalam pertanggung jawaban dan tanggung gugat yang harus diterima oleh perawat selaku penerima pelimpahan wewenang.

\section{Tanggung Jawab Perdata Perawat Dalam} Praktek Keperawatan Tindakan Sirkumsi Yang Ada Dalam Klinik.

Menurut hukum tanggung jawab merupakan suatu akibat atas konsekuensi seseorang terhadap kebebasan tentang perbuatannya yang berkaitan dengan suatu etika ataupun moral dalam melakukan suatu perbuatan $^{35}$. Pertanggung jawaban dapat terwujud apabila terdapat beberapa unsur yang telah sesuai untuk terlaksananya suatu pertanggung jawaban, Unsur tersebut berupa adanya suatu peristiwa yang menyebabkan timbulnya hak hukum bagi seseorang untuk menuntut orang lain memenuhinya dan adanya suatu kewajiban hukum untuk orang lain memberi dan menjalankan suatu pertanggung jawaban yang telah dibuatnya. ${ }^{36}$

Praktek mandiri keperawatan, perawat dapat menjalankan suatu pertanggung jawaban apabila perawat dalam praktek mandiri tersebut telah melakukan suatu kerugian pada pasien. Pertanggung jawaban perawat bila dilihat berdasarkan ketentuan "KUHPerdata" dapat dikategorikan pada pertanggung jawaban secara langsung dan mandiri yang berdasarkan pada ketentuan "Pasal 1365 dan 1366 KUHPerdata", yang berbunyi sebagai berikut ${ }^{37}$, "Setiap orang bertanggung jawab, bukan hanya atas kerugian yang disebabkan perbuatanperbuatan, melainkan juga atas kerugian yang disebabkan kelalaian atau kesembronoannya".

Berdasarkan ketentuan tersebut dapat disimpulkan bahwa perawat dalam praktek keperawatan tindakan medis sirkumsi apabila perawat tersebut telah melakukan kerugian kepada pasien maka perawat berkewajiban

35 Soekidjo Notoatmojo, Etika dan Hukum Kesehatan, Rineka Cipta, Jakarta, 2010, hlm. 45

36 Titik Triwulan dan Shinta Febrian, Perlindungan Hukum bagi Pasien, Prestasi Pustaka, Jakarta, 2010, hlm.48

37 Lihat Pasal 1366 Kitab UndangUndang Hukum Perdata.

Universitas Trunojoyo Madura 
untuk bertanggung jawab secara mandiri kepada pasien yang telah mengalami kerugian karena perbuatan yang telah diberikan perawat dalam tindakan medis khitan tersebut. Dalam hal tersebut pasien memiliki hak untuk menuntut perawat memberikan ganti rugi atas perbuatan yang dilakukan perawat kepada pasien dan karena perbuatannya tersebut pasien mengalami kerugian ataupun kecacatan pada dirinya. Hak pasien untuk meminta perawat memberikan ganti rugi atas perbuatannya telah diatur didalam ketentuan "Pasal 58 Undang Undang Nomor 36 Tahun 2009 Tentang Kesehatan" yang berisi ${ }^{38}$, "Setiap orang berhak menuntut ganti rugi terhadap seseorang, tenaga kesehatan, dan/atau penyelenggarakesehatan yang menimbulkan kerugian akibat kesalahan atau kelalaian dalam pelayanan kesehatan yang diterimanya".

Pasien dapat mengajukan gugatan ataupun tuntutan ganti rugi apabila pasien tersebut telah dirugikan oleh perawat atas tindakan melanggar hukum yang dilakukan perawat kepada pasien dan berakibat kerugian yang diderita oleh pasien.Pelimpahan wewenang adalah suatu wewenang yang dilimpahkan kepada perawat yang telah memiliki keterampilan dan kemampuan dalam menjalankan suatu tindakan yang dilimpahkan. Pelimpahan wewenang terbagi menjadi dua macam pelimpahan yang dapat diterima oleh perawat yaitu pelimpahan wewenang secara mandat

38 Lihat Pasal 58 Undang-Undang Nomor 36 Tahun 2009. dan pelimpahan wewenang delegatif. Perawat sebagai penerima pelimpahan wewenang dapat melakukan suatu tindakan medis kepada pasien dan apabila dalam menjalankan tindakan medis berdasarkan pelimpahan wewenang terjadi suatu kerugian yang dialami pasien ataupun klien maka perawat sebagai penerima pelimpahan wewenang turut serta dalam menanggung tanggung jawab serta tanggung gugat atas kerugian yang dialami oleh pasien ataupun klien.

Pelimpahan wewenang secara mandat merupakan suatu pelimpahan wewenang yang diterima oleh perawat untuk menjalankan suatu tindakan medis kepada pasien ataupun klien dengan pengawasan tenaga medis dalam proses tindakan medis yang dilakukan perawat. Apabila dalam tindakan medis yang dilakukan oleh perawat terdapat suatu kerugian yang dialami oleh pasien ataupun klien maka tenaga medis terkait sebagai pemberi wewenang berkewajiban untuk bertanggung jawab atas kerugian yang diderita oleh pasien ataupun klien.

Pelimpahan wewenang secara mandat apabila terjadi suatu kerugian yang dialami oleh pasien atupun klien maka tanggung jawab hukum secara perdata berdasarkan pada "Pasal 1367 KUHPerdata" yang inti dari pasal tersebut berupa suatu pihak tidak hanya bertanggung jawab atas suatu tindakannya yang menimbulkan suatu kerugian akan tetapi harus menanggung kerugian yang ditimbulkan oleh orang-orang yang berada dalam tanggungannya. Berdasarkan isi pasal 
tersebut dapat disimpulkan bahwa dalam pelimpahan wewenang secara mandat dokter dan perawat berkewajiban menanggung tanggung jawab serta tanggung gugat secara bersama dalam tanggung jawab hukum perdata atas kerugian yang diderita oleh pasien ataupun klien. ${ }^{39}$

Pelimpahan wewenang delegatif adalah suatu pelimpahan yang diterima oleh perawat untuk menjalankan suatu tindakan medis. Dalam pelimpahan wewenang secara delegatif tenaga medis selaku pemberi pelimpahan wewenang secara delegatif memberikan kewenangan kepada perawat untuk menjalankan suatu tindakan medis beserta tanggung jawab dan tanggung gugat yang harus diterima oleh perawat selaku penerima pelimpahan wewenang secara delegatif.

Apabila dalam suatu tindakan medis yang dilakukan perawat kepada pasien ataupun klien terjadi suatu kerugian yang dialami oleh pasien ataupun klien maka perawat berkewajiban bertanggung jawab berdasarkan tanggung jawab hukum perdata terkait dengan perbuatannya tersebut yang berdasarkan pada "Pasal 1366 KUHPerdata" yang berisi bahwa "setiap orang berkewajiban bertanggumg jawab atas perbuatannya yang menimbulkan kerugian serta atas kelalain dan kesembronoannya yang dapat menimbulkan suatu kerugian". 40

Berdasarkan pada pasal tersebut dapat

39 Lihat Pasal 1367 Kitab UndangUndang Hukum Perdata

40 Lihat Pasal 1366 Kitab UndangUndang Hukum Perdata. disimpulkan bahwa perawat dalam menjalankan tindakan medis berdasarkan pelimpahan wewenang delegatif memiliki wewenang dalam memberikan tindakan medis kepada pasien sesuai dengan keterampilan dan kemampuan yang dimilikinya dan tidak melakukan tindakan medis tertentu yang dirasa perawat tersebut tidak mampu dan belum memiliki keterampilan dalam melakukan tindakan medis tersebut.

Apabila perawat dalam melakukan tindakan medis kepada pasien ataupun klien terjadi suatu kerugian yang diderita oleh pasien ataupun klien maka perawat berkewajiban untuk bertanggung jawab sepenuhnya karena dalam pelimpahan wewenang secara delegatif tidak hanya kewenangan dalam melakukan tindakan medis saja yang diberikan tenaga medis selaku pemberi pelimpahan wewenang akan tetapi tanggung jawab dan tanggung gugat juga harus diterima oleh perawat selaku penerima pelimpahan wewenang. Tanggung jawab hukum secara perdata yang harus ditanggung oleh perawat berdasar pada Pasal 1366 KUHPerdata apabila dalam tindakan medis yang dilakukan oleh perawat terjadi suatu kerugian yang ditimbulkan dan diderita oleh pasien ataupun klien maka perawat berkewajiban bertanggung jawab sepenuhnya dan memberikan ganti rugi kepada pasien atau klien atas perbuatannya tersebut.

Saat keadaan darurat setiap tenaga kesehatan berkewajiban untuk memberikan pertolongan kepada klien ataupun pasien untuk mencegah terjadinya kecacatan 
ataupun kehilangan nyawa. Perawat sebagai bagian dari tenaga kesehatan memiliki wewenang untuk memberikan pertolongan pada saat keadaan darurat, Dalam keadaan darurat perawat dapat melakukan tindakan medis dan pemberian obat yang sesuai dengan kompetensinya dengan tujuan sebagai pertolongan pertama pada saat keadaan darurat.

Tindakan medis yang dilakukan perawat dalam keadaan darurat telah diatur didalam ketentuan terkait yang merupakan suatu tanggung jawab yang harus dijalankan perawat sebagai salah satu bagian dari tenaga kesehatan. ${ }^{41}$ Dalam keadaan darurat perawat tidak berhak memberikan ganti rugi kepada pasien ataupun klien yang merasa dirugikan karena keadaan darurat dapat terjadi secara mendadak dan keadaan darurat tidak ditimbulkan oleh perawat atas tindakannya, perawat hanya menjalankan tugasnya sebagai pemberi tindakan penyelamatan nyawa dan pencegahan kecacatan yang dapat diderita oleh pasien atau klien dalam keadaan darurat. $^{42}$

Berdasarkan pengertian tersebut dapat disimpulkan bahwa dalam keadaan darurat perawat diperbolehkan untuk melakukan tindakan medis dan pemberian obat kepada klien ataupun pasien untuk mencegah terjadinya kecacatan dan kehilangan nyawa yang dapat diderita oleh pasien ataupun klien, Tindakan medis dan pemberian obat dalam

\footnotetext{
41 Lihat Pasal 33 Peraturan Menteri Kesehatan Nomor 26 Tahun 2019

42 Lihat Pasal 58 Undang-Undang Nomor 36 Tahun 2009 Tentang Kesehatan.
}

keadaan darurat dapat dilakukan oleh perawat sebagai tindakan pertolongan pertama agar tidak menimbulkan kecacatan bahkan kehilangan nyawa yang dapat dialami oleh pasien ataupun klien, apabila tindakan tersebut telah diberikan oleh perawat maka perawat berkewajiban untuk merujuk pasien atau klien ke dokter ataupun ke fasilitas pelayanan kesehatan karena perawat hanya sebatas sebagai pemberi pertolongan pertama dengan cara melakukan tindakan medis dan pemberian obat yang sesuai dengan kompetensinya yang merupakan tanggung jawab perawat yang berdasarkan ketentuan "Pasal 33 tentang Keadaan darurat Peraturan Menteri Kesehatan Nomor 26 Tahun 2019.”

Penugasan pemerintah pada keadaan keterbatasan tertentu perawat dapat memberikan pelayanan asuhan keperawatan serta dapat melakukan pelayanan kesehatan lainnya seperti melakukan tindakan medik berdasarkan pelimpahan wewenang kepada pasien ataupun klien, apabila dalam suatu wilayah tersebut tidak terdapat tenaga medis maupun tenaga kefarmasian karena perawat yang menjalankan penugasan pemerintah pada keadaan keterbatasan tertentu telah dibekali dengan pelatihan dan orientasi yang dilakukan oleh kepala dinas kesehatan Pemerintah Daerah Kabupaten/Kota.

Apabila dalam menjalankan penugasan pemerintah pada keadaan keterbatasan tertentu terjadi suatu kerugaian yang dialami oleh pasien ataupun klien terkait pelayanan asuhan keperawatan maupun tindakan medis yang dilakukan oleh perawat maka perawat berkewajiban untuk bertanggung jawab 
secara hukum perdata secara sepenuhnya dengan memberikan ganti rugi atas tindakannya yang mengakibatkan kerugaian yang dialami oleh pasien ataupu klien.

\section{SIMPULAN}

Sirkumsi adalah suatu tindakan medis yang dalam prosesnya dilakukan oleh tenaga medis dan dapat juga dilakukan oleh perawat berdasarkan adanya pelimpahan wewenang yang diberikan secara tertulis oleh tenaga medis kepada perawat yang pelimpahan wewenang tersebut terdiri atas pelimpahan wewenang secara mandat dan delegatif yang sesuai pada "Pasal 27 Peraturan Menteri Kesehatan No 26 Tahun 2019". Dalam praktek keperawatan tindakan sirkumsi dapat dilakukan oleh perawat berdasarkan pada adanya pelimpahan wewenang secara delegatif yang diterima perawat untuk menjalankan suatu tindakan medis berupa tindakan khitan disertai dengan pelimpahan tanggung jawab yang harus ditanggung oleh perawat dalam menjalankan tugas pelimpahan wewenang secara delegatif.

Apabila dalam praktek keperawatan tindakan medis berupa sirkumsi berdasarkan pelimpahan wewenang secara delegatif terjadi suatu kerugian yang dialami oleh pasien ataupun klien dalam hubungan hukumnya perawat harus bertanggung jawab sepenuhnya atas tindakannya yang mengakibatkan kerugian kepada pasien ataupun klien karena dalam pelimpahan wewenang secara delegatif, tenaga medis memberikan wewenang kepada perawat profesi ataupun perawat vokasi untuk menjalankan suatu tindakan medis berdasarkan kompetensi dan pelatihan yang telah dijalani oleh perawat profesi maupun perawat vokasi tersebut. Dalam menjalankan praktek keperawatan, perawat menjalankan pelayanan praktek keperawatan secara mandiri dan berkolaborasi dengan Tenaga kesehatan lain.

Tanggung jawab perdata perawat dalam menjalankan tindakan medis berdasarkan tugas pelimpahan wewenang apabila dalam tindakan medis yag dilakukan oleh perawat kepada pasien ataupun kliennya terjadi suatu kerugian berupa kecacatan yang harus dialami oleh pasien atau klien maka perawat harus bertanggung jawab sepenuhnya atas tindakannya yang mengakibatkan kerugian berupa kecacatan yang dialami oleh pasien ataupun klien karena tindakan medis berupa tindakan sirkumsi memiliki risiko tinggi dalam pelakasanaannya.

Untuk menjalankan tugas pelimpahan wewenang perawat diberi kewenangan oleh tenaga medis untuk menjalankan suatu tindakan medis serta pelimpahan tanggung jawab juga harus diterima oleh perawat dalam menjalankan tugas pelimpahan wewenang karena tenaga medis memberikan suatu wewenang untuk menjalankan tindakan medis kepada perawat profesi dan perawat vokasi yang telah terlatih dan sesuai dengan kompetensinya dan apabila tindakan medis berpa tindakan sirkumsi tersebut dilakukan oleh perawat atas dasar pelimpahan wewnang secara mandat maka apabila terjadi suatu kerugian ataupun kecacatan yang dialami oleh pasien ataupu klien maka tenaga medis terkait yang menanggung kerugian yang iderita oleh pasien tersebut, karena tindakan medis secara pelimpahan wewenang mandat dijalankan perawat dengan pengawasan langsung oleh tenaga medis terkait yang berdasarkan pada “ 
Pasal 28 Peraturan Menteri Kesehatan Nomor 26

Tahun 2019".

\section{DAFTAR RUJUKAN}

H.S, Salim. (2004). Hukum Kontrak: Teori \& Teknik Penyusunan Kontrak. Jakarta: Sinar Grafika

Mahmud Marzuki, Peter. (2005). Penelitian Hukum Jakarta: Kencana

Notoatmojo, Soekidjo. (2010). Etika dan Hukum Kesehatan, Jakarta: Rineka Cipta

R.Y, Hutabarat, \& Putra, C. S. Asuhan. (2016). Keperawatan Kegawatdaruratan. Bogor: In Media

Suwignyo. (2007). Pengaruh Manajemen Asuhan Keperawatan dan Motivasi Berprestasi. Jakarta: Gramedia
Pustaka Utama

Triwulan, Titik dan Shinta Febrian. (2010). Perlindungan Hukum bagi Pasien. Jakarta: Prestasi Pustaka

Tribowo Cecep. (2010). Hukum Keperawatan, Yogyakarta: Pustaka Book Publisher Tribowo, Cecep. (2010). Hukum Keperawatan, Yogyakarta, Cet I, Pustaka Book Publisher

Notoatmodjo, Soekidjo. (2010) Etika \& Hukum Kesehatan, Jakarta: Rineka Cipta

Bustami, (2010), Penjamin Mutu Pelayanan Kesehatan dan Akseptabilitasnya. Jakarta: Erlangga

Kusnanto. (2004). Pengantar Profesi \& Praktik Keperawatan Profesional, Jakarta: EGC (Diakses pada 30 desember 2020 Pukul 23.58 WIB). 